\title{
Importance of specific IgM antibodies in 116 patients with various stages of syphilis
}

\author{
S MERLIN,* J ANDRE,*† B ALACOQUE, ‡ AND A PARIS-HAMELIN\& \\ From *Service de Sérologie-Nelson, Institut Pasteur de Lyon et du Sud-Est, Lyon, †Laboratoire \\ d'Immunologie et de Technologie Microbienne, Département de Microbiologie et Immunologie \\ Pharmaceutiques, Université Claude-Bernard, Lyon, $¥$ Département de Vénérologie, l'Hôpital de \\ l'Antiquaille, Lyon, and §Centre National de Référence et de Recherche pour les Tréponématoses, Institut \\ Alfred-Fournier, Paris, France
}

SUMMARY We tested 222 serum samples obtained from 51 patients presenting with syphilis, before and after treatment; 117 from 65 patients with a history of syphilis (114) or yaws (3); 77 from 71 patients with no evidence of syphilis; and 1117 serologically negative serum samples.

Our tests included the IgM fluorescent treponemal antibody absorbed (IgM-FTA-ABS) and solid phase haemadsorption assay (SPHA) techniques. According to the stage of development of syphilis, IgM antibodies were found in $83-100 \%$ of the serum samples. This permitted a precise diagnosis to be made and cure assessed. As IgM antibodies were absent in serum from patients with healed syphilis, resolved syphilis could be distinguished from developing syphilis.

The sensitivity $(92 \%)$ of the IgM-FTA-ABS test was comparable with that of the SPHA $(96 \%)$, but the SPHA was more specific $(97 \cdot 4 \%)$ than the IgM-FTA-ABS test $(89 \cdot 61 \%)$.

\section{Introduction}

Serological screening for syphilis as part of routine examination has been improved by the introduction of specific tests, the Treponema pallidum haemagglutination assay (TPHA) and the fluorescent treponemal antibody absorbed (FTA-ABS) test. The use of quantitative tests, however, permits a more consistent approach to monitoring the disease.

In the absence of clinical features of the disease the standard serological tests (Venereal Disease Research Laboratory (VDRL), TPHA, and FTA-ABS) do not always permit detection of early incubating syphilis. Several workers have shown that the measurement of specific IgM antibodies to $T$ pallidum may be useful in diagnosing active syphilis. ${ }^{1-4}$

Specific IgM antibodies can be measured by immunofluorescence using an anti- $\mu$ chain serum labelled with fluorescein, the IgM-FTA-ABS test. Because of the possible errors inherent in this test, such as false positive results caused by rheumatoid factors and false negative results caused by competitive inhibition by high titre IgG antibodies, other techniques have been proposed. Some of these

Address for reprints: Miss S Merlin, Service Sérologie-Nelson, Institut Pasteur de Lyon, 77 Rue Pasteur, 69365 Lyon Cedex 7, France

Accepted for publication 2 July 1984 were based on the separation of IgM from IgG antibodies by ultracentrifuging, ${ }^{5-7}$ exclusiondiffusion chromatography, ${ }^{2}$ S89 affinitychromatography, ${ }^{51011}$ ion-exchange chromatography, ${ }^{11}$ and IgM absorption by protein A of Staphylococcus aureus. ${ }^{12}$ After separation, the antibody activity of the IgM fraction was studied by immunofluorescence (19S(IgM)-FTA) or haemagglutination (TPHA).

Other tests included binding a human anti-IgM antibody to a solid phase, as in the anti-IgM enzyme linked immunosorbent assay (ELISA) of StrandbergPedersen $e t$ al $^{13}$ or by using the solid phase immunosorbent technique (SPIT) of Krech, ${ }^{14}$ who proposed this technique to measure IgM in both rubella and syphilis. The test was modified by Schmidt to diagnose syphilis and called the solid phase haemadsorption assay (SPHA). ${ }^{15}$ Since then several workers have made use of this technique. ${ }^{11}{ }^{16-19} \mathrm{We}$ used it to assess the importance of specific IgM antibodies in diagnosing syphilis, as it was more applicable than previous methods requiring the separation of IgG and IgM antibody. Our attempts at reproducing the exact technique described by Schmidt failed, as all serum samples positive in the TPHA were also positive in the SPHA (S Merlin, unpublished observations). We therefore used a modification of the method described by Denoyel et al for rubella. ${ }^{20}$ The purpose of our work was twofold: (a) to develop a 
method for routinely detecting IgM antibodies specific to $T$ pallidum, and (b) to assess the clinical importance of the test.

\section{Patients, materials, and methods}

We tested 1533 samples of serum and two of cerebrospinal fluid (CSF) obtained from 1304 patients infected with syphilis, untreated and treated, and patients with no evidence of syphilis. Serum of patients with syphilis was supplied by the department of Professor Moulin, Hôpital de l'Antiquaille, Lyon, France.

\section{UNTREATED PATIENTS}

Patients with primary, early secondary, secondary, or latent syphilis

We obtained 32 serum samples from 29 patients in whom a diagnosis of active syphilis had been established on the basis of clinical or serological features (table I), nine of whom had diagnoses of latent syphilis on the basis of positive serology but had no clinical signs.

TABLE I Stages of syphilis in the 29 patients with active untreated disease

\begin{tabular}{lcc}
\hline Stage of syphilis & No of patients & No of serum samples \\
\hline Primary & 5 & 6 \\
Early secondary & 2 & 2 \\
Secondary & 13 & 15 \\
Latent & 9 & 9 \\
Total & 29 & 32 \\
\hline
\end{tabular}

\section{Reinfected patients}

We obtained a further five serum samples from two of the 13 patients with secondary syphilis who were reinfected during follow up (one patient suffered from primary syphilis, the other from secondary syphilis).

\section{Patients with neurosyphilis}

We obtained three samples of serum and two of CSF from three patients presenting with neurosyphilis, in one of whom it was atypical.

\section{TREATED PATIENTS}

Patients with primary, early secondary, secondary, or latent syphilis or reinfection

We obtained 296 serum samples from 111 patients (including the 29 mentioned above) after they had been treated for active syphilis. Table II shows the stages of the disease at the time of treatment and the number of serum samples obtained at various intervals after treatment. Three further serum samples were from two patients with healed yaws, one of whom had presented with lymphogranuloma venereum.

PATIENTS WITH NO EVIDENCE OF SYPHILIS The department of Professor Larbre, Hôpital Debrousse, Lyon, supplied serum samples from 59 children aged 4 to 17 , who were in hospital for various illnesses. We also tested six serum samples from five patients who were undergoing other investigations, for whom clinical and serological findings showed they did not have syphilis; nine serum samples from five pregnant women with false positive results for cardiolipin; one serum sample from a patient with genital herpes; two serum samples from a patient with aphthous ulceration of the genitalia; six serum samples containing antinuclear antibodies (immunofluorescence titres ranging from $1 / 5$ to $1 / 5120) ; 12$ serum samples containing rheumatoid factor (titres ranging from $1 / 0$ to $1 / 1280$ by the Waaler-Rose technique, and from $1 / 80$ to $1 / 2560$ by the Behring latex fixation technique) supplied by the laboratories of immunology and immunopathology of Institut Pasteur de Lyon et du Sud-Est; and 1099 serum samples from patients attending the Institut Alfred-Fournier, Paris, for routine screening for sexually transmitted diseases.

TABLE II Number of serum samples obtained from 111 patients with various stages of syphilis at various intervals after treatment

\begin{tabular}{|c|c|c|c|c|c|c|}
\hline \multirow{2}{*}{$\begin{array}{l}\text { Stage of syphilis } \\
\text { (No of patients) }\end{array}$} & \multicolumn{6}{|c|}{ No of serum samples obtained at following intervals after treatment: } \\
\hline & 10 days & $11-30$ davs & 1-6 months & $7-12$ months & $13-24$ months & $2-36$ vears \\
\hline $\begin{array}{l}\text { Primary (21) } \\
\text { Early secondary (7) } \\
\text { Secondary (27) } \\
\text { Latent }(45) \\
\text { Undefined (11) }\end{array}$ & $\begin{array}{l}3 \\
2 \\
3\end{array}$ & $\begin{array}{r}5 \\
9 \\
11 \\
8\end{array}$ & $\begin{array}{l}13 \\
19\end{array}$ & $\begin{array}{r}9 \\
5 \\
9 \\
51\end{array}$ & $\begin{array}{r}8 \\
7 \\
15\end{array}$ & $\begin{array}{r}21 \\
8 \\
21 \\
47 \\
17\end{array}$ \\
\hline $\begin{array}{l}\text { Reinfections with: } \\
\text { Primary syphilis (1) } \\
\text { Secondary syphilis (1) }\end{array}$ & 1 & & 2 & $\begin{array}{l}1 \\
1\end{array}$ & & \\
\hline
\end{tabular}


We tested all the samples for antibodies to $T$ pallidum by the VDRL (Institut Pasteur Production (IPP), Marnes la Coquette, France) and TPHA (Fujirebio, Tokyo, Japan) tests. The FTA-ABS test was performed on 416 serum samples.

The SPHA was undertaken as follows to show specific IgM antibodies: round bottomed microtitration plates were sensitised with $100 \mu l$ human anti-IgM serum (Dakopatts, Copenhagen, Denmark), diluted in carbonate-bicarbonate buffer (pH 9.6). After being incubated overnight at $37^{\circ} \mathrm{C}$ they were washed three times in phosphate buffered

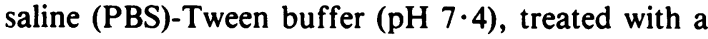
$1 \%$ bovine serum albumin solution in PBS-Tween buffer for two hours at $37^{\circ} \mathrm{C}$, and washed three times in PBS buffer. Serum samples diluted $1 / 10$ in the absorbent of TPHA (Fujirebio) according to the geometric progression: $\mathrm{n}=\mathrm{a} \times \mathrm{r}^{\mathrm{n}-1}$ (when $\mathrm{a}=$ $1 / 10$ dilution and $r=2$ ) were added to the plates, which were incubated for three hours at $37^{\circ} \mathrm{C}$ and then washed three times with PBS buffer. The bound IgM antibodies were shown by application of $50 \mu \mathrm{l}$ of a 1/30 dilution of red blood cells sensitised to Treponema pallidum (Fujirebio). A control serum was prepared with $50 \mu \mathrm{l}$ of a 1/30 dilution of non-sensitised red cells, and control red cells diluted in buffer only were prepared. The reaction was judged to be positive when complete haemagglutination occurred at the bottom of the plate; borderline if haemagglutination manifested itself by the occurrence of a ring in the centre; and negative if red cell sedimentation exhibited a small ring.

The IgM-FTA-ABS test was undertaken as follows: serum samples were diluted $1 / 10$ in sorbent (Biomerieux, Charbonnieres les Bains, France) and then in PBS buffer, and were incubated with the antigen (Pasteur) deposited on a glass slide. The dilution of human anti-IgM serum labelled with fluorescein (Pasteur) was measured for each batch. The reaction was positive if the intensity of
TABLE III Results of IgM-FTA-ABS test and SPHA in 25 serum samples from patients with untreated primary, early secondary, secondary, and neurosyphilis

\begin{tabular}{llll}
\hline \multirow{2}{*}{$\begin{array}{l}\text { Results } \\
\text { of SPHA }\end{array}$} & \multicolumn{4}{l}{ Results of IgM-FTA-ABS test: } \\
\cline { 2 - 4 } & Positive & Negative & Total \\
\hline Positive & 23 & 1 & 24 \\
Negative & 0 & 1 & 1 \\
Total & 23 & 2 & 25 \\
\hline
\end{tabular}

fluorescence was ++ or more and borderline if less than ++ .

Serum samples (diluted 1/20) that gave borderline or positive results in the IgM-FTA-ABS test or the SPHA, or both, were screened for rheumatoid factor by the Behring latex fixation test (Behringwerke, Hamburg, West Germany). If agglutination was noted, a quantitative test was performed.

\section{Results}

\section{UNTREATED PATIENTS WITH ACTIVE SYPHILIS} (table III)

Patients with primary syphilis

Of the six serum samples, five $(83 \%)$ contained IgM antibodies with titres ranging from $1 / 10$ to $1 / 5120$ in the SPHA, and from $1 / 20$ to $1 / 640$ in the IgM-FTAABS test.

Patients with early secondary and secondary syphilis All 17 serum samples contained specific IgM antibodies with titres ranging from $1 / 20$ to $1 / 327680$ in the SPHA, and from $1 / 40$ to $1 / 1280$ in the IgMFTA-ABS test.

\section{Patients with latent syphilis}

In the nine serum samples, the SPHA showed specific IgM antibodies in only two (titres $1 / 10$ and $1 / 40$ ) and the IgM-FTA-ABS test showed them in three (titres $1 / 20,1 / 40$, and $1 / 80$ ).

TABLE IV Progressive fall in IgM antibodies in 111 patients treated for syphilis

\begin{tabular}{|c|c|c|c|c|c|c|}
\hline \multirow{2}{*}{$\begin{array}{l}\text { Stage of syphilis } \\
\text { (No of patients) }\end{array}$} & \multicolumn{6}{|c|}{$\begin{array}{l}\text { No of serum samples obtained at following intervals after treatment (No giving negative results in } \\
\text { parentheses) }\end{array}$} \\
\hline & 10 days & $11-30$ days & 1-6 months & 7.12 months & 13-24 months & $2-36$ years \\
\hline $\begin{array}{l}\text { Primary (21) } \\
\text { Early secondary (7) } \\
\text { Secondary (27) } \\
\text { Latent (45) } \\
\text { Undefined (11) }\end{array}$ & $\begin{array}{l}3\left(1^{*}, 1+\right) \\
2\left(0^{*}, 0+\right) \\
3\left(3^{*}, 2+\right)\end{array}$ & $\begin{array}{r}5\left(1^{*}, 0+\right) \\
9\left(4^{*}, 3+\right) \\
11\left(0^{*}, 1+\right) \\
8\left(7^{*}, 7+\right)\end{array}$ & $\begin{array}{l}13\left(11^{*}, 8 \dagger\right) \\
19\left(9^{*}, 11+\right)\end{array}$ & $\begin{array}{c}9\left(8^{*}, 5 \dagger\right) \\
5\left(3^{*}, 3 \dagger\right) \\
9\left(8^{*}, 8+\right) \\
51\left(49^{*}, 46+\right)\end{array}$ & $\begin{array}{c}8\left(8^{*}, 8+\right) \\
7\left(6^{*}, 5 \dagger\right) \\
15\left(14^{*}, 11+\right)\end{array}$ & $\begin{array}{l}21\left(14^{*}, 13 \dagger\right) \\
8\left(8^{*}, 4 \dagger\right) \\
21\left(8^{*}, 10+\right) \\
47\left(41^{*}, 40+\right) \\
17\left(15^{*}, 15 \dagger\right)\end{array}$ \\
\hline $\begin{array}{l}\text { Reinfections with: } \\
\text { Primary syphilis (1) } \\
\text { Secondary syphilis (1) }\end{array}$ & $1\left(0^{*}, 0 \dagger\right)$ & & $2\left(1^{*}, 1+\right)$ & $\begin{array}{l}1\left(0^{*}, 0+\right) \\
1\left(1^{*}, 1+\right)\end{array}$ & & \\
\hline
\end{tabular}

${ }^{*}$ No of serum samples giving negative results in SPHA.

†No of serum samples giving negative results in FTA-ABS test. 


\section{Patients with neurosyphilis}

The serum samples from the two patients with typical neurosyphilis contained specific IgM antibodies at titres of $1 / 80$ in the SPHA and $1 / 40$ and $1 / 160$ in the IgM-FTA-ABS test, as did the two samples of CSF (titres $1 / 20$ and $1 / 640$ in the SPHA, and $1 / 10$ and $1 / 40$ in the IgM-FTA-ABS test). The serum sample from the patient with atypical neurosyphilis proved positive only in the SPHA (titre 1/2560).

\section{Reinfected patients}

Both the SPHA and the IgM-FTA-ABS test showed the reappearance of IgM antibodies in all serum samples from these two patients, and titres in the VDRL test and TPHA increased concurrently.

\section{TREATED PATIENTS}

Table IV shows the progressive fall in IgM antibodies after treatment.

\section{Ten days to 24 months after treatment}

An appreciable (at least fourfold) decrease in IgM antibodies was observed within 20 days to four months after treatment (mean 1.3 months) in the SPHA, and within 20 days to nine months (mean 3.4 months) in the IgM-FTA-ABS test. IgM antibodies completely disappeared within: three to 12 months of treatment for primary syphilis (in the IgM-FTA-ABS test and SPHA); 40 days to 22 months of treatment for early secondary syphilis (in the SPHA); three to eight months of treatment for early secondary syphilis (in the IgM-FTA-ABS test); and two to 16 months of treatment for secondary syphilis (in the SPHA and IgM-FTA-ABS test).

In the 62 serum samples from patients with latent syphilis specific IgM antibodies were detected in three by the SPHA and seven by the IgM-FTA-ABS test, although few had contained specific IgM antibodies before treatment. In the patient reinfected with secondary syphilis the specific IgM antibodies disappeared within four months after further treatment.

\section{Two to 36 years after treatment}

Of the 63 patients in this group, serum from 52 did not contain IgM antibodies in the SPHA or the IgMFTA-ABS test, and serum from 11 (38 samples), whose results were stable in the VDRL test, TPHA, and FTA-ABS test, had positive or unrelated results in both the SPHA and the IgM-FTA-ABS test. Of the three patients with a history of yaws, only the one with lymphogranuloma venereum had serum giving positive results. Both his serum samples gave borderline results in the SPHA (titres $1 / 40$ and 1/160) and positive results in the IgM-FTA-ABS test (titres 1/10 and $1 / 20)$.
NON-INFECTED PATIENTS

Table $\mathrm{V}$ shows results for the 77 serum samples collected. The SPHA gave positive results in two, borderline (titre 1/40) in a child, and borderline (titre $1 / 20$ ) in a patient with genital herpes. The specificity of the SPHA was therefore $97.4 \%$ (confidence interval 92-99\%; $p=0.9$ ). The IgM-FTA-ABS test gave positive results in eight samples, six of which were from children (titres 1/20-1/40), one sample from a pregnant woman was borderline (titre 1/40), and serum from one patient with genital herpes gave a borderline result (titre 1/20). The specificity of the IgM-FTA-ABS test was therefore $89.61 \%$ (confidence interval $82-95 \% ; p=0.9$ ).

Six serum samples that contained antinuclear antibodies and 1099 from patients attending for routine examination were negative in both the SPHA and the IgM-FTA-ABS test. Of 12 serum samples containing rheumatoid factor, in the SPHA three had borderlines reactions (one with a titre of $1 / 10$, two with a titre of 1/40); in the IgM-FTA-ABS test five gave borderline reactions (four with a titre of $1 / 40$ and one with a titre of $1 / 80$ ), and one gave a positive reaction (titre $1 / 160$ ).

TABLE V Results of IgM-FTA-ABS test and SPHA in 77 serum samples from patients with no evidence of syphilis

\begin{tabular}{llcc}
\hline \multirow{2}{*}{$\begin{array}{l}\text { Results } \\
\text { of SPHA }\end{array}$} & \multicolumn{3}{l}{ Results of lgM-FTA-ABS test: } \\
\cline { 2 - 4 } & Positive & Negative & Total \\
\hline Positive & 2 & 0 & 2 \\
Negative & 6 & 69 & 75 \\
Total & 8 & 69 & 77 \\
\hline
\end{tabular}

TESTS FOR RHEUMATOID FACTOR

We investigated 145 serum samples with borderline or positive reactions in the SPHA or IgM-FTA-ABS test, or both, for the presence of rheumatoid factor. It was found in 22 serum samples obtained from one patient with early secondary syphilis and from two patients with previously treated syphilis.

\section{Discussion}

Testing for specific IgM antibodies to $T$ pallidum seems to be a solution to the shortcomings of the serological tests to diagnose syphilis. The presence of these antibodies supports the diagnosis of active syphilis requiring treatment. The absence of specific IgM antibodies (whether serological tests give positive or negative results) may help to exclude a diagnosis of syphilis or may confirm the effectiveness of the treatment. 
Both the SPHA and the IgM-FTA-ABS test showed the presence of IgM antibodies in all patients with active syphilis. In the patient with atypical neurosyphilis, only the SPHA showed IgM antibodies, which supported the diagnosis. Such data agree with other published reports. Lefèvre et al, ${ }^{21}$ Hagedorn, ${ }^{22}$ and Leclerc et $a^{23}$ did not detect IgM antibodies by the IgM-FTA-ABS test in serum or CSF from any of their patients with neurosyphilis. Competitive inhibition by high titres of IgG antibodies to $T$ pallidum may account for these findings, as Herbst $e t$ al, using the 19S(IgM) FTA-ABS test, ${ }^{8}$ and Luger et al, using the SPHA, ${ }^{18}$ detected these antibodies in practically all the patients they studied.

As table III shows, the sensitivity of the SPHA can be estimated as $96 \%$ (confidence interval $82-100 \%$; $\mathrm{p}=0.9$ ), while the sensitivity of the IgM-FTA-ABS test was $92 \%$ (confidence interval 76-98\%; $p=0.9$ ). Such data show the diagnostic value of measuring IgM antibody.

Both the SPHA and the IgM-FTA-ABS test detected the reappearance of IgM antibodies in patients who were reinfected. Two workers failed to detect IgM antibodies in all their reinfected patients by the IgM-FTA-ABS test. ${ }^{18}{ }^{21}$ This might have been due to a phenomenon of steric competition, as Luger et al succeeded in detecting these antibodies after either separating IgM and IgG antibodies (19S(IgM)-FTA) or by a method of selecting IgM antibodies (SPHA). ${ }^{18}$

In a third (3/9) of the patients with latent syphilis the diagnosis was confirmed by the presence of IgM antibodies. In five of the six remaining patients in whose serum IgM was not found, results of serological tests (VDRL, THPA, and FTA-ABS) remained stable after treatment. Thus, testing for IgM antibodies permitted the correction of a diagnosis of latent syphilis in the five patients, and use of the tests may be important in differentiating between active disease and properly treated syphilis. In one of the six patients, the serum was reactive for 10 months after treatment, with appreciable falls in titres from 1/64 to 1/8 in the VDRL test and from $1 / 40960$ to $1 / 10240$ in the TPHA. Possible explanations are: technical failure of the SPHA and IgM-FTA-ABS test, failure to detect IgM antibodies by the IgM-FTA-ABS test owing to steric competitive inhibition by IgG antibodies, ${ }^{26} 27$ the varying presence of IgM antibodies, ${ }^{28}$ or the intake of unprescribed antibiotics by the patient during the three weeks between the two serological tests were performed before the known treatment was started.

Our results show that IgM antibodies subside and disappear within three to 12 months of treatment in patients with primary syphilis, and within two to 22 months in patients with secondary syphilis. Other studies have shown that the time between starting treatment for primary syphilis and the disappearance of IgM antibodies was: one month, ${ }^{7}$ three to six months, ${ }^{324}$ and up to 12 months. ${ }^{425}$ As regards secondary syphilis, the interval ranged from four to eight months, ${ }^{7}$ or from three to 18 months. ${ }^{34}$ Müller found an interval of 12 months for both secondary and tertiary syphilis and he proposed a two year follow up period after treatment. ${ }^{24}$

As the lapse of time before total disappearance of IgM antibodies varies, a follow up study of the time antibodies take to decline seems to be more interesting than the knowledge of absolute titres at which reactions occur. Any appreciable decrease in IgM antibodies may be interpreted as evidence of therapeutic success. The disappearance or appreciable decrease in titres of specific IgM antibodies represents a sound basis for the assessment of cure of syphilis, in addition to its use in routine clinical evaluation.

The absence of IgM antibodies in 52 patients with previously treated syphilis seems to corroborate the hypothesis that syphilis is no longer active when IgM disappears. As regards the 11 patients in this group in whom the SPHA or the IgM-FTA-ABS test, or both, gave positive or dissociated results, the problem of the specificity of reactions should be taken into account (one patient often suffered from urethritis, another from recurrent herpes, some serum samples had been obtained from a woman at postpartum examination, and those from two other patients contained rheumatoid factor). Another problem to be taken into account is that of the threshold of reactions and that of borderline reactions-for example, 15 serum samples from six patients gave borderline results in the SPHA or the IgM-FTA-ABS test, or both.

We conclude that the SPHA and the IgM-FTAABS test are equally sensitive, but the specificity of the SPHA is higher $(97 \cdot 4 \% v 89.6 \%)$. Identifying specific IgM antibodies to $T$ pallidum appears to be essential in establishing a consistent diagnosis of syphilis. Positive test results (a) allow a diagnosis of active syphilis to be made; (b) distinguish between latent syphilis, reinfection, and atypical syphilis; and (c) indicate that treatment is required. Negative test results help to (a) exclude a diagnosis of active syphilis by detecting residual antibody levels (in patients with previously treated syphilis); (b) identify false positive serological reactions; (c) confirm cure by demonstrating a rapid fall in antibody titres; and (d) establish criteria for healed syphilis.

We propose that the SPHA be used as reference standard for the following conditions: (a) active syphilis (positive SPHA results); (b) latent syphilis (no clinical signs, positive serology, and positive 
SPHA results); (c) reinfection (the titres of SPHA rise again); (d) residual antibody (history of infection, positive serology, and negative SPHA results); (e) false positivity (no history of infection, positive serology, and negative SPHA results); and (f) healing syphilis (negative SPHA results).

We thank Mr P Adeleine and Mr J J Milan (of the Hospices Civils de Lyon, Laboratoire d'Informatique Médicale, Department of Professor Site) for their assistance in our statistical calculations, and the documents they supplied.29 30

\section{References}

1. Atwood WG, Miller JL. Fluorescent treponemal antibodies in fractionated syphilitic sera. The immunoglobulin class. Arch Dermatol 1969; 100: 763-9.

2. Müller F, Loa PL. Neue Möglichkeiten in der immunologischen Diagnostik der Treponemen Infektion (Syphilis). Infection 1974;2:127-31.

3. O'Neill P, Nicol CS. IgM class antitreponemal antibody in treated and untreated syphilis. British Journal of Venereal Diseases 1972; 48: 460-3.

4. Wilkinson AE, Rodin P. IgM-FTA test in syphilis in adults: its relation to clinical findings. British Journal of Venereal Diseases 1976; 52:219-23.

5. Mühlenberg W, Müller-Prasuhn G, Höpken W. Möglichkeiten und Grenzen den IgM-FTA-Abs tests in der Routine Serodiagnostik der Lues. Zentralbl Bakteriol Mikrobiol Hyg [A] 1981; 249: 104-23.

6. Paris-Hamelin A, Vaisman A, Fustec-Ibarboure S, Crajer MC, Montezin $\mathbf{M}$, Petit $\mathbf{V}$. La réaction d'hémagglutination passive pour le sérodiagnostic de la syphilis. III-Séparation des immunoglobulines par ultracentrifugation en gradient de saccharose à partir de sérums de syphilitiques. Son intérêt dans l'étude de la sensibilité et de la précocité de divers sérodiagnostics. Médecine et Maladies Infectieuses 1974;4: $537-43$.

7. Shannon R, Booth SD. The pattern of immunological responses at various stages of syphilis. British Journal of Venereal Diseases 1977; 53:281-6.

8. Herbst BR, Goerz G, Müller F. Diagnostischer und therapeutischer Aussagewert des IgM-FTA-Abs und IgMFTA-19Ss tests bei der Syphilis. Aktuelle Dermatologie 1979; 5: 175-83

9. Volkerding R, Müller F. Modellversuche zur Wirkung von IgM und IgG Antikörpen auf die Reaktivităt des Treponema pallidum Hämagglutination (TPHA) Tests. Hautarzt 1976; 27: 26-9.

10. Huschka U, Maier J, Rauterberg EW, Doerr HW. Rapid separation of immunoglobulin $\mathbf{M}$ by immunoaffinity chromatography for detection of specific antibodies to Rubella and Treponema pallidum. Eur J Clin Microbiol 1982;1:118-21.

11. Huschka U, Stengel HH, Schroeter R, Roelcke D, Doerr HW. Rapid detection of Treponema pallidum and cytomegalovirus specific IgM antibodies with the passive haemagglutination test. Zentralbl Bakteriol Mikrobiol Hyg [A] 1982; 253:120-30.

12. Mohr FW, Schneweis KE. Der FTA-Abs IgM Test im Vergleich zur quantitativen Cardiolipin-Reaktion und zum TPHA Test. Aerztliche Laboratorium 1976;22:305-10.
13. Strandberg-Pedersen N, Pedersen CS, Axelsen NH. Enzymelinked immunosorbent assay for detection of immunoglobulin $\mathrm{M}$ antibody against the Reiter Treponema flagellum in syphilis. J Clin Microbiol 1982; 16:608-14.

14. Krech U. Solid phase immunosorbent technique (SPIT) for the demonstration of specific IgM antibodies by haemagglutination inhibition and passive haemagglutination. Dev Biol Stand 1979;44:139-45.

15. Schmidt BL. Solid phase hemadsorption: a method for rapid detection of Treponema pallidum-specific IgM. Sex Transm Dis 1980; 7: 53-8.

16. Brun $\mathbf{R}$. Essai d'une nouvelle méthode sérologique pour la détection de la syphilis active. Dermatologica 1982; 165:254-8.

17. Luger A, Gschnait F, Schmidt BL. Der SPHA-test in der serologischen Diagnostik der syphilis. Wien Klin Wochenschr 1981;93:506-8.

18. Luger A, Schmidt BL, Schonwald E. Die SPHA Technik (Solid-Phase-Hămadsorption) in der Syphilisserologie Einjährige Erfahrung im Routinebetrieb. Hautarzt 1982;33: 138-44.

19. Müller F, Lindenschmidt E-G. Demonstration of specific 19S(IgM) antibodies in untreated and treated syphilis: comparative studies of the 19S(IgM)-FTA test, the 19S(IgM)-TPHA test, and the solid phase haemadsorption assay. British Journal of Venereal Diseases 1982;58:12-7.

20. Denoyel GA, Gaspar A, Peyramond D. Diagnosis of recent rubella virus infection by demonstration of specific immunoglobulin $\mathbf{M}$ antibodies: comparison of solid-phase reverse immunosorbent test with sucrose density gradient centrifugation. J Clin Microbiol 1981;13:698-704.

21. Lefèvre JC, Larrouy G, Bauriaud R, Daber-Bernat H, Abbal M, Prere MF. Classes d'immunoglobulines (IgM/IgG) retrouvées dans les sérums de syphilitiques aux différents stades de l'affection (Apport du FTA-Abs IgM/IgG). Médecine et Maladies Infectieuses 1979;9:206-11.

22. Hagedorn HJ. Syphilisantikorper im Liquor cerebrospinalis und ibre diagnostische Bedeutung. Dtsch Med Wochenschr 1980; 105: 155-61.

23. Leclerc G, Giraux M, Birry A, Kasatiya S. Study of fluorescent treponemal antibody test on cerebrospinal fluid using monospecific anti-immunoglobulin conjugates $\operatorname{IgG}$, IgM, and IgA. British Journal of Venereal Diseases 1978;54:303-8.

24. Muller F. Der 19S(IgM) FTA-Abs Test in der serodiagnostik der syphilis: Technik, Fehlermoglichkeiten und diagnostische Aussage. Immun Infekt 1982;10:23-34.

25. Luger A, Schmidt B, Spendlingwimmer I. Quantitative evaluation of the FTA-Abs IgM and VRDL test in treated and untreated syphilis. British Journal of Venereal Diseases 1977;53:287-91.

26. Müller F. Zur Technik des Nachweises treponemenspezifischer 19S-IgM Antikorper bei der latenten und spätlatenten syphilis. Immun Infekt 1977; 5: 109-13.

27. Müller F, Oelerich S. Korrelation immunologischer Parameter zu den Stadien der apparenten und der Klinisch stummen syphilis. Dermatol Monatsschr 1979; 165:385-95.

28. Shannon R, Copley CG, Morrison GD. Immunological responses in late syphilis. British Journal of Venereal Diseases 1980;56:372-6.

29. Morice E, Chartier F. Méthode statistique. Paris: Institut National de la Statistique et des Etudes Economiques pour la Metropole et la France d'Outre Mer (INSEE), 1954.

30. Galen RS, Gambino SR. Beyond normality: the predictive value and efficiency of medical diagnosis. New York: J Wiley and Sons, 1975. 